\title{
DISCOURSE OF VHF COMMUNICATION AT SEA AND THE INTERCULTURAL ASPECT
}

\author{
Milena Dževerdanović-Pejović ${ }^{1}$ \\ ${ }^{1}$ Faculty of Maritime Studies, Kotor, University of Montenegro
}

Received 10 January 2013; accepted 30 May 2013

\begin{abstract}
Discourse analysis of real examples of internal and external communication at sea represents a real challenge for linguists. Research in this field is at its very beginning and was partially presented in the final report of the MARCOM project (1999). The main reason for this is the scarcity of the available VHF material and on-board verbal recordings. This paper explored to what extent the rules for radio conversation are applied in the segments of real verbal communication between ships at sea, especially with regard to application of the Standard Marine Communication Phrases (SMCP), set by the International Maritime Organization (IMO) in 2001. Using knowledge of conversation analysis as a peculiar branch of discourse analysis and intercultural communication theories dealing with multi-cultural crewing issues, the special emphasis was given to the formal/informal, official/unofficial and standardized/non-standardized discourse dichotomies.
\end{abstract}

Keywords: discourse analysis, verbal communication, standardized/non-standardized discourse, SMCP.

\section{Introduction}

Due to exceptional circumstances connected to the nature of seafaring, research of verbal communication conducted at sea is a rather tricky undertaking due to only partially available sources which could be used for the purpose of linguistic analysis (particularly at the level of the text and discourse). More precisely, it is not ethical to publish VHF transcripts and on-board verbal recordings between ships as they can be compromising for ship masters and officers involved in internal and external communication.

What is more, it is well known that these items of communication represent valid proof in post-accident investigations, so it makes the collection of an empirical corpus of maritime communication a very hard enterprise.

As said in the above text, the VHF and VDR (voyage data recording) transcripts are usually offered as an appendix to the accident reports and statements written by ship masters. However, if the VHF transcript is available, a discourse analyst must take a rather forensic approach to a discourse which has emerged in the verbal internal and external conversation. It must be mentioned that the application of SMCP (The Standard Marine Communication Phrases), which were introduced by the International Maritime Organization in 2001, is still questionable due to the existence of a gap

\footnotetext{
${ }^{1}$ Corresponding author: milenadz@ac.me
} 
between the prescribed and the real use of language by seafarers. The main goal of these phrases is to minimize miscommunication between seafarers who speak different languages and to prevent situations which, apart from technical errors, have led to serious accidents at sea. Therefore, the IMO SMCP is designed to cover the most crucial verbal shore-to-ship (and vice-versa), ship-to-ship and on-board communication. Bearing in mind this standardized language code, the paper analyzes compliance and non-compliance with the phrases in communication between two or more stations, not only in routine situations, but more importantly, in emergencies at sea.

Transcripts of the VHF communication along with document transcripts of voyage data recorder involving the ships Maersk Kendal, Cosco Busan and Royal Majesty presented in this paper are used for the sake of comparative analysis of the prescribed and real communication at sea and are taken from the Internet.

The author of this paper has explored numerous maritime accidents in order to grasp the practical use of the so-called "limited languages" or "codes" such as are SMCP in seafaring and this paper therefore presents another author's discursive undertaking to explore a peculiar maritime profession and maritime communication.

\section{Methodology and Corpus}

Collection of the VHF material is rather a difficult task bearing in mind the specific maritime context in which a certain discourse has appeared. Because of fear that the transcripts of such communication may be misused, most sea masters and shipping companies only unwillingly publish such material. Only a few complete transcripts have recently become available on the Internet, such as the transcript of the sinking of the Estonia in 1994. Material used in this paper is collected from the Marine Accident Investigation Branch - MAIB, offering abundance of pre and post accident VHF transcripts.

The problem which a discourse analyst faces in the analysis of verbal language material is how to analyze and interpret data in which human behaviour and discourse are merged. As Lazaraton (2009) put it, it is necessary to have background knowledge of the situation in which a discourse appears.

As regards the methodological approach taken in this paper, the very context, participants and their roles and relations in the given maritime context governed the author in the analysis. Hence, the analysis combines discursive and "mental" aspect, that is, the linguistic facts need to be interpreted from the social and psychological aspect if the situation dictates so.

For example, knowing that turn-talking in the verbal maritime radio communication is organized, the author uses knowledge of conversational theories like in the case of Maersk Kendal analysis (Goffman, 1976; Schegloff, 1992), particularly with regard to a successive organization of verbal interaction (adjacency pairs). The application of conversation theory in this paper regarding turns and conversational pairs set by implicit or explicit rules of communication is used to establish relations existing between the semiotic and pragmatic dimension of text (Gotti, 2008).

Apart form discursive analysis given in this paper, the gap between formal and informal 
discourse and the relationship between the prescribed and real communications at sea in some cases demanded an intercultural approach (like in the cases of ships Royal Majesty and Cosco Busan). Hence, the author relied on the theory of cultural script (Wierzbicka, 2006) and sociolinguisticallyoriented works (Pyne and Koester, 2005).

\section{Application of the Conversational Theory-Analysis of the VHF Segment of the Ship Maersk Kendal}

The grounding of the ship Maersk Kendal, registered under the British flag in 2009 is among numerous examples of marine accidents which have arisen due to bad communication. Although the ship was warned of the danger of the neighbouring vessels in the sea traffic, the Maersk Kendal did not reduce its speed on time, nor did it change its course so as to avoid running aground. During radio communication on the VHF channel, the master of the ship Maersk Kendal misinterpreted information received from the vessel traffic information service regarding the position of the three ships in the immediate vicinity of the Maersk Kendal. Apart from the ship Maersk Kendal $(\mathrm{MK})$, the remaining participants in the communication are the Vessel Traffic Information Service (VTIS) and the ships Bright Pacific (BP) and Kota Delima (KD).

What follows is a VHF transcript of shipto-shore and ship-to-ship communication before grounding of the ship Maersk Kendal (Table 1):

Table 1

VHF Transcript of Ship-to-Ship and Ship-to-Shore Communication before the Grounding of the Ship Maersk Kendal

\begin{tabular}{|c|c|c|}
\hline Line & Participant & Content \\
\hline 1 & VTIS & Maersk Kendal, Maersk Kendal, VTIS. \\
\hline 2 & MK & VTIS, Maersk Kendal. \\
\hline $\begin{array}{l}3 \\
4\end{array}$ & VTIS & $\begin{array}{l}\text { Maersk Kendal, require that you slow down. Three ships coming out of the } \\
\text { Jurong channel ahead of you. }\end{array}$ \\
\hline 5 & MK & I can confirm that we have slowed down sir. \\
\hline $\begin{array}{l}6 \\
7 \\
8 \\
9\end{array}$ & VTIS & $\begin{array}{l}\text { Thank you very much, keep a good lookout. For your information, bearing } \\
\text { from you } 267 \text { degrees just under } 3 \text { nautical miles away is Kota Delima, } \\
\text { Kota Delima going to EAST. Behind her, motor tanker Bright Pacific going } \\
\text { to EAST. } \\
\text { Exercise caution, over. }\end{array}$ \\
\hline 10 & MK & Understood sir. \\
\hline 11 & $\mathrm{KD}$ & Maersk Kendal, Maersk Kendal, Kota Delima on your starboard bow. \\
\hline 12 & MK & Kota Delima, this is Maersk Kendal replying. \\
\hline 13 & $\mathrm{KD}$ & Your starboard bow, on your starboard bow, I crossing on your head. \\
\hline 14 & MK & Yes sir-You can cross, cross my bow. \\
\hline 15 & $\mathrm{KD}$ & Thank you. \\
\hline 16 & VTIS & Maersk Kendal, Maersk Kendal, VTIS. \\
\hline 17 & MK & VTIS, Maersk Kendal. \\
\hline $\begin{array}{l}18 \\
19 \\
20 \\
\end{array}$ & VTIS & $\begin{array}{l}\text { Bearing from you } 277 \text { degrees, distance } 2 \text { nautical miles away is the } \\
\text { departure tanker Bright Pacific, Bright Pacific going to EAST. What are } \\
\text { your intentions? Passing ahead or astern of her, over. }\end{array}$ \\
\hline
\end{tabular}




\begin{tabular}{|c|c|c|}
\hline 21 & MK & We will pass astern of her. \\
\hline 22 & & You will pass astern of her. (Pause) Her name is Bright Pacific, if necessary \\
\hline 23 & VTIS & you can call her, you can call her. And your speed is very high, your speed \\
\hline 24 & & still very high. You are entering our port limit now. \\
\hline 25 & MK & We are slowing down sir, speed is coming down. \\
\hline 26 & VTIS & Bright Pacific, Bright Pacific, VTIS. \\
\hline 27 & $\mathrm{BP}$ & This is Bright Pacific, go ahead. \\
\hline 28 & & Bright Pacific, on your port bow bearing 100 degrees distance 105 nautical \\
\hline 29 & VTIS & miles away there is the container Maersk Kendal, Maersk Kendal (unclear) \\
\hline 30 & & will pass astern of you. \\
\hline $\begin{array}{l}31 \\
32\end{array}$ & $\mathrm{BP}$ & $\begin{array}{l}\text { Thank you very much sir, the container vessel on my port bow. Maersk } \\
\text { vessel, she will pass astern of me. Thank you very much sir. }\end{array}$ \\
\hline 33 & VTIS & Thank you. \\
\hline 34 & VTIS & Maersk Kendal, Maersk Kendal, VTIS. \\
\hline 35 & MK & VTIS, Maersk Kendal. \\
\hline 36 & VTIS & Are you the captain over? \\
\hline 37 & MK & Sir, the captain is on the bridge, go ahead. \\
\hline $\begin{array}{l}38 \\
39\end{array}$ & VTIS & $\begin{array}{l}\text { Captain on the bridge. Right now, you are already in the port limits, advice } \\
\text { you to slow down your speed, slow down your speed, there is a lot of.......... } \\
\text { stuff.........over. }\end{array}$ \\
\hline 40 & MK & Understood sir. \\
\hline $\begin{array}{l}41 \\
42\end{array}$ & MK & $\begin{array}{l}\text { (Captain) VTIS, Maersk Kendal, Maersk Kendal, listen, I am slowing } \\
\text { down all the time, I have two ships ahead and will pass astern of both of } \\
\text { them, no problem. }\end{array}$ \\
\hline $\begin{array}{l}43 \\
44\end{array}$ & VTIS & $\begin{array}{l}\text { Chemical Tanker, Chemical Tanker, the name is Samho Jewelry, Samho } \\
\text { Jewelry is a piloted tanker. She is not leaving Singapore, she is not leaving } \\
\text { Singapore. }\end{array}$ \\
\hline 45 & MK & Got the name of the tanker - Samho Jewelry. Thank you. \\
\hline 46 & VTIS & Thank you, it appears that you are heading towards her, over. \\
\hline 47 & VTIS & Maersk Kendal, Maersk Kendal, VTIS. \\
\hline 48 & MK & Unclear. \\
\hline 49 & & All ships stand by, all ships stand by. Maersk Kendal, warning to you, \\
\hline $\begin{array}{l}50 \\
51\end{array}$ & VTIS & $\begin{array}{l}\text { ahead of you is chemical tanker Samho Jewelry, Samho Jewelry pilot on } \\
\text { board. She is going to, she is going to..... }\end{array}$ \\
\hline $\begin{array}{l}52 \\
53\end{array}$ & VTIS & $\begin{array}{l}\text { Maersk Kendal, Maersk Kendal, VTIS warning to you, ahead of you is } \\
\text { chemical tanker Samho Jewelry, Samho Jewelry. What is your intention } \\
\text { over? }\end{array}$ \\
\hline 54 & MK & We are passing astern and will make an alteration to port after that. \\
\hline $\begin{array}{l}55 \\
56\end{array}$ & VTIS & $\begin{array}{l}\text { Captain, next time, next time exercise caution please. Navigate with safe } \\
\text { speed, Captain you cannot navigate like that. }\end{array}$ \\
\hline 57 & VTIS & Maersk Kendal, Captain do you copy? \\
\hline 58 & VTIS & Maersk Kendal? \\
\hline 59 & VTIS & Maersk Kendal, Maersk Kendal, VTIS. \\
\hline 60 & MK & UNCLEAR. \\
\hline 61 & VTIS & Maersk Kendal, shallow water ahead of you, shallow water ahead of you. \\
\hline 62 & MK & Ok sir. \\
\hline
\end{tabular}




\begin{tabular}{lll}
\hline 63 & VTIS & Maersk Kendal, VTIS? \\
\hline 64 & VTIS & Maersk Kendal, VTIS? \\
\hline 65 & VTIS & Maersk? \\
\hline 66 & MK & VTIS, Maersk Kendal. \\
\hline 67 & VTIS & Maersk Kendal, are you aground? \\
\hline 68 & MK & That is affirmative sir! \\
\hline
\end{tabular}

Source: MAIB (2009)

\subsection{Conversation Constraints}

Every communication has explicit and implicit rules which are followed in discourse. Thus, the participant knows when and how to take part in conversation, to include other participants in the communication or shift communication to other participants as well. Goffman's (1976) central concept was the institution of social interaction. He claimed that "the institutional order of interaction has a particular social significance. It underlies the operations of all the other institutions in society, and it mediates the business they transact" (Heritage,
2001). According to Goffman (1976), the process of interaction is prone to universal constraints. However, in each language there are ways to deal with these constraints, depending on the communication channel. Communication constraints are systematic (internal constraints pertaining to a specific language system) and ritual constraints (constraints pertaining to non-linguistic aspects i.e. the social context in which communication is shaped). Goffman (1976) lays down seven signs of conversation constraints which were found relevant to the comparative analysis of the VHF language material in this paper (Table 2).

\section{Table 2}

Communication Constraints According to Goffman (1976) as Elaborated in Hatch (1992) Applied to VHF Communication at Sea

\begin{tabular}{ll}
\hline Communication constraints signals & Examples from VHF communication \\
\hline $\begin{array}{l}\text { 1. Signals aimed at starting and closing communication } \\
\begin{array}{l}\text { 2. Signals confirming that communication has been } \\
\text { established }\end{array}\end{array}$ & Maersk Kendal, This is VTIS. \\
\hline $\begin{array}{l}\text { 3. Signals aimed at shifting communication from one } \\
\text { participant to the other }\end{array}$ & Switch to channel 16. \\
\hline $\begin{array}{l}\text { 4. Signals aimed at making communication clear } \\
\text { 5. Signals aimed at transferring communication and } \\
\text { signals of digression }\end{array}$ & How do you read me, I repeat, how do you read me? \\
\hline $\begin{array}{l}\text { 6. Signals aimed at preventing other participants to } \\
\text { interfere in communication }\end{array}$ & All ships - Keep silence on radio channel! \\
\hline 7. Signals aimed at ending communication & Over; Out. \\
\hline
\end{tabular}

Bearing in mind the above stated signals of communication constraints set by Goffman (1976), as elaborated by Hatch (1992), the analysis goes on with identifying these signals in the above-given transcript of the VHF communication involving the ship Maersk Kendal and other participants (Table 1). 


\subsubsection{Signals Aimed at Starting and Closing Communication}

The Standard Marine Communication Phrases (SMCP) are written by the model of already established aviation language set by ICAO (International Civil Aviation Organization). Thus, a typical signal of opening discourse in a two-way communication is the use of the vocative, i.e. calling out the ship by name twice $(1,11)$. Identification includes the name of the ship (station) being called pronounced once (2), but for the sake of clear communication, the deictic element "this" is used (12):

\begin{tabular}{lll}
1 & VTIS & Maersk Kendal, Maersk Kendal, VTIS. \\
\hline 2 & MK & VTIS, Maersk Kendal. \\
\hline
\end{tabular}

\begin{tabular}{lll}
\hline 11 & KD & Maersk Kendal, Maersk Kendal, Kota Delima on your starboard bow. \\
\hline 12 & MK & Kota Delima, this is Maersk Kendal replying. \\
\hline
\end{tabular}

Looking at the transcript from Table 1, instead of the use of the prescribed "out" for ending communication, more informal variations are used such as "Understood sir" (lines 10, 40), "Thank you" (lines 15, 32, 45), whereas the ship Maersk Kendal, at the end of very confusing and unclear radio communication with the vessel traffic information service (VTIS), when it was already clear that grounding could not be avoided, answers curtly with "Ok, sir" (62).

\subsubsection{Signals Confirming that Communication has been Established}

The signal which is used to show that communication has been established, i.e. that the station recipient is ready to receive the message in the given segment of the VHF interaction, is the phrase "go ahead" in the sentence "This is Bright Pacific, go ahead" (Table 1, line 27). In the other examples of VHF conversation, the signal stating that the message has been received is "Roger" or very frequent use of "Do you copy" (Table 1, line 57), as in "Maersk Kendal, Captain, do you copy?".

\subsubsection{Signals Aimed at Shifting Communication from one Participant to the other}

Among many signals whose pragmatic use is aimed at shifting communication from one participant to the other, the most prominent is "over" meaning " $I$ /we have finished with my/ our message and I am/we are ready to receive yours" (Table 1, lines 9, 18, 20, 39, 46, and 53). Signals which are not present in Table 1 but are also used in the same "shifting" purpose are "Switch/go to channel", i.e. "Switching/going to channel...".

\subsubsection{Signals Aimed at Making Communication Clear}

The signals aimed at making the whole or part of the communication clear are mainly lexical ones (repetition of words or a group of words). In the above given example of VHF communication (Table 1), it can be identified that the most relevant information is repeated as in: "If necessary you can call her, call her", "Your speed is very high, very high" (Table 1, lines 22, 23). 


\subsubsection{Signals Aimed at Transferring Communication and Signals of Digression}

Signals of digression and signals of transferring communication are not found in Table 1. The reason for this is because all the time the VTIS station is focused on the proper guidance of communication in the channel and on the prevention of interference from other stations in communication.

\subsubsection{Signals Aimed at Preventing other Participants to Interfere in Communication}

Of the signals which are aimed at preventing the communication process and are given in Table 1, we find: "All ships stand by, all ships stand by" (line 50) indicating the emergency of the situation at sea and warning the nearby stations to pay attention to the radio messages which will follow.

In the case of the discourse, this is realized through the use of interrogative sentences such as "Are you the Captain, over" (line 36), "What is your intention, over?" (line 53), but also through the usage of the imperative so that it can be seen that the Vessel Traffic Information Service (VTIS) is taking over the role of arbitrator: "All ships stand by!", "Next time exercise caution!" (line 55), "Captain, you cannot navigate like that!" (line 56). In that sense, VTIS not only "controls" navigation in the channel but also controls the discourse.

\subsubsection{Signals Aimed at Ending Communication}

Typical signals used to end the conversation are "over" and "out" and their use is properly distributed throughout the text in Table 1.
The first one, "over" means that the speaker has finished his/her message but has not ended the conversation, whereas "out" indicates total ending of communication in the adjacency pair call-answer.

\subsection{Conversation Exchange}

The procedures of leading conversation in VHF discourse are similar to those laid down in Schegloff's model (Schegloff, 1992). The unit of the analysis is turn whereas the exchange is seen as a unit of spontaneous conversation depending on the context. In addition, conversation turn is a relevant occurrence in the analysis of successive conversation and the analysis of speech acts (Savić, 1998).

As Schegloff (1992) put it, in the procedure of conducting the conversation, there are (a) procedures in which the speaker chooses the next speaker, or (b) procedures in which the next speaker is self-elected. (The first rule implies that the speaker calls out the next one as is the case in the majority of communication exchanges in the illustrated conversation exchange in Table 1 , where the party calling out is mainly the vessel traffic information service and the speaker is called out by name).

However, the very situation at sea imposes the rule that if a particular ship notices another ship visually or on radar in its immediate vicinity, and there is the slightest danger of maritime accident, the first ship must notify the other ship on the VHF channel about the imminent danger and therefore becomes the self-elected speaker in the conversation. Thus, although the vessel traffic information service is the main initiator of discourse activities in the given segment of discourse, the "self-elected" participant in the following 
situation is the ship Kota Delima. The ship Kota Delima notifies the ship Maersk Kendal about the manoeuvre of overtaking just in case the overtaken ship makes an unexpected deviation from the existing course line. What follows is the short communication extract from Table 1 showing the ship-toship communication:

\begin{tabular}{lll}
\hline 11 & KD & Maersk Kendal, Maersk Kendal, Kota Delima on your starboard bow. \\
\hline 12 & MK & Kota Delima, this is Maersk Kendal replying. \\
\hline 13 & KD & Your starboard bow, on your starboard bow, I crossing on your head. \\
\hline 14 & MK & Yes sir-You can cross, cross my bow. \\
\hline 15 & KD & Thank you. \\
\hline
\end{tabular}

This segment of communication confirms Schegloff's opinion that "speaker transfer is taken to be an accomplishment, achieved as a consequence of mutually coordinated speaker sensitivity to those procedures or conventions for effecting such a change. It is locally managed by the parties involved, that is, an interactional achievement coordinated "on the spot" (Wooffitt, 2005).

Also, the hierarchy of the VHF discourse is achieved owing to the existence of conversation turns which to the greatest extent make the constructs of many conversation activities as seen by Schegloff
(1992) and Heritage (2001). Heritage gives the more specific formulation and says that the adjacency pair is "a sequence of two utterances which are adjacent, produced by different speakers, ordered as a first part and second part and typed, so that a first part requires a particular second, or range of second parts" (Wooffitt, 2005).

Examples of such pairs in general language are question-answer, invitation-response, or greeting-greeting pairs. A typical adjacency pair in maritime VHF communication is callanswer in the VHF exchange. Therefore, the relation call-answer is strictly hierarchized as was shown in segments of Table 1 :

\begin{tabular}{lll}
\hline 36 & VTIS & Are you the captain over? \\
\hline 37 & MK & Sir, the captain is on the bridge, go ahead.
\end{tabular}

or

\begin{tabular}{l|l|l}
\hline 52 & VTIS & $\begin{array}{l}\text { Maersk Kendal, Maersk Kendal, VTIS warning to you, ahead of you is chemical } \\
\text { tanker Samho Jewelry, Samho Jewelry. What is your intention over? }\end{array}$ \\
\hline 53 & MK & We are passing astern and will make an alteration to port after that. \\
\hline
\end{tabular}

\subsection{Examples of Compliance and Non- Compliance with the SMCP}

The fact is that limited languages, more precisely, the Standard Marine Communication Phrases set up for communication at sea make verbal interaction in some situations artificial and blurred. It is more important for the "prescribed" linguistic forms (vocabulary, phrases, cohesive elements) to assume different meanings in real situations on board ships. Among many objections assigned to the use of the SMCP by linguists and professionals in the maritime sector is that "the greater the temptation to 
direct the language of maritime communication, the more distant such a language from the direct users is (crew and passengers), as well as from the other members of the maritime discourse community" (MARCOM Project, 1999). For this reason, it is justifiable to expect deviations from the standard procedures in practice.

For example, when addressing the ship Maersk Kendal (Table 1), the vessel traffic information service does not use the message marker request for expressing the illocutionary act of request, nor the verb reduce instead of slow down. Therefore "... require that you slow down" is put instead of the proper message marker: "REQUEST: Reduce your speed". Also, the sentence: "Warning to you, ahead of you is chemical tanker" (line 49), should be written as: "WARNING: Chemical tanker ahead of you".

Analogously, the ship responding to the request of the ship Maersk Kendal continued the conversation in an informal style: " $I$ can confirm that we have slowed down, sir" (5). The use of "sir" indicates the tacit practice of showing respect for the operators of the radio station, being an authoritative body regulating traffic in a seaway.

On the other hand, "sir" represents the way of addressing seniors in a military discourse so it can be assumed that it represents the language heritage of the discourse of pilots in air traffic, as the phrases used in aviation communication were used as the model for composing the Standard Marine Communication Phrases. However, it can be concluded that the language of radio operators is closer to the standard as they use certain specific phrases such as "keep a good lookout" (line 6), "What are your intentions?" (line 19). As for the usage of the Standard Marine Communication Phrases, prominent is the use of the pronoun "she" i.e. "her" in the third person singular meaning "the ship" as representative of the maritime context.

Resentment of the ship Maersk Kendal owing to frequent directives which it repeatedly received from the vessel traffic service may be noticed in a discourse as well. This is why we can imply the slight reprimand in the utterance in which the captain of the ship Maersk Kendal directly addresses, in an informal tone, the vessel traffic information service (VTIS), after numerous conversation exchanges made between these two stations: "Captain, listen, I am slowing down all the time, I have two ships ahead and I will pass astern both of them, no problem" (Table 1, lines 41, 42). In addressing the vessel traffic information service, the use of the imperative "listen" is entirely improper for the existing discourse. In addition, the subject of the communication is thrice personalized (e.g. "I am slowing down"; "I have two ships"; "I will pass") in comparison with the prescribed use of the impersonal pronoun " $w e$ " and used in the previous segments of the VHF communication.

Likewise, the more the vessel traffic information service becomes aware of the imminent collision, the weaker the illocutionary force of the discourse is. According to the theory of speech acts (Austin, 1994), utterances have two types of meaning: (a) propositional meaning, i.e., the act of locution is recognized as a certain message which consists of certain words and structures making the utterance, and (b) illocutionary meaning, i.e., the real effect 
which the utterance has on the speaker in relation to the previous said and the context.

In that sense, it is not clear whether the declarative sentences uttered by the vessel traffic information service (Table 1, line 44) "She is not leaving Singapore, she is not leaving Singapore" is notification or warning, as the vessel Maersk Kendal understood the name of the ship, but not the purpose of the message (line 45): "Got the name of the tanker-Samho Jewelry. Thank you".

Uncertainty and deviation from a standardized discourse is continued, thus the operators of the same service "chat" in everyday language using the verb of perception appear in the it construction (46): "It appears that you are heading towards her, over". Following the directives prescribed by the Standard Marine Communication Phrases, it should be written as follows: "Information/Warning: You are heading towards her", whereas her should be replaced by the name of the ship (Samho Jewelry). Because more than three vessels are participating in the conversation, it is necessary to emphasise the name of each ship individually.

The unfinished sentence (lines 50,51) uttered by the vessel traffic information service contributes to the impression of uncertainty and panic: "Warning to you ...Samho Jewelry she is going to, she is going to...". Finally, there is a sharp criticism uttered by the vessel traffic information service radio operator who is, as it has been said before, not only the regulator of sea traffic, but the regulator of a discourse as well (line 56): "Captain you cannot navigate like that". Some of the reasons which contributed to the grounding of the ship Maersk Kendal are the ship's negligence, particularly in view of paying attention to warnings broadcast by the vessel traffic service and over-frequent language interventions made by it. Also, the initial vessel traffic service's compliance with the Standard Marine Communication Phrases gradually attenuated and the discourse became rather informal. At the end, the master and the first deck officer of the ship Maersk Kendal misinterpreted information received from the vessel traffic information service in view of the ships that the vessel traffic service mentioned in its warnings.

It may be concluded that the efficiency of discourse led by the vessel traffic information service mainly depended on the: reliability, timing of information giving and language clarity. The most important thing, however, should have been the establishing of balance between broadcasting short and clear messages on the one hand, and achieving economy of utterance in the working channel, on the other.

\subsection{Recent Research on Discursive Aspects of Seafaring Language and Intercultural Issues}

From the establishment of the IMO SMCP in 2001, linguists, and more precisely, the English language teachers involved in teaching Maritime English as the English for Specific Purposes, have investigated the real application of the SMCP in VHF communication. The SMCP stands for the revised and improved version of the earlier established, the Standard Marine Navigational Vocabulary (SMNV, 1987). 
This, often called "artificial language or code" adopted in 1977, was a linguistic attempt to overcome differences and misunderstandings among seafarers at sea.

The SMCP, however, as the enhanced version of the SMNV focuses on the shore communications as well, more precisely, on standardizing the language used not only at communications at sea and on board, but also the language used in ports and among personnel employed at coast and radio stations.

Both codes have been the subject of linguistic analysis, more precisely, many authors have compared to what extent the prescribed linguistic norm, especially in radio communication, is really applied at communication at sea. Valuable works by Pritchard (2003) and Bocanegra (2010) use contemporary linguistic theories like discourse analysis and genre theory to explore discursive features of the SMCP.

Lastly, tendency towards exploring the seafaring profession has also included the sociolinguistics aspects of shipboard life. There is no doubt that English language as the lingua franca onboard ship implies some cultural and mental scripts.

These also reflect on the variations in conducting standardized language at sea. Raising awareness that language is a link but the barrier too, has given rise to theories reflecting the impact of Anglophone mental patterns on the life onboard. The approach used by the author in this paper relies on the work of Wierzbicka (2006) and the work of Pyne and Koester (2005) and is applied in the analysis of code-switching situations like in the cases of VHF communication of Royal Majesty and Cosco Busan.

\section{Analysis of the VHF Communication of the Ship Royal Majesty}

The grounding of the ship Royal Majesty near Massachusetts in 1995 is one of numerous marine accidents in which technical factors and bad communication both contributed to the bad outcome of the situation at sea. The focus of the analysis is one segment of the communication which was conducted among a group of Portuguese ships on VHF channel 16.

The ship Royal Majesty deviated from the course due to failure of navigational equipment although the ship's crew were not aware of the technical deficiency. However, it soon became clear that the ship Royal Majesty was navigating toward danger.

The crew from the Portuguese ship addressed Royal Majesty in English. Yet, this address contained no warnings about danger despite the fact that the internal communication conducted between the Portuguese fishing vessels in Portuguese indicated danger. As a consequence, the crew on board the ship Royal Majesty did not realize that they were close to grounding. In the final report made after the accident it was concluded that if the messages communicated between Portuguese ships had been conducted in English, the crew of the Royal Majesty would have paid attention to them and thus would have avoided an accident. Here is a segment of the VHF transcript (Table 3). 


\section{Table 3}

Segment of the VHF Communication between the Portuguese Ships and MV Royal Majesty

(1) 2042 fishing vessel ( $f / v)$ Sao Marcos [in English language]: "Fishing vessel, fishing vessel call cruise boat."

(2) $2043 \mathrm{f} / v$ Rachel E [In Portuguese]: "Are you there Toluis [nickname Tony Sao Marcos]?"

(3) $f / v$ Sao Marcos [In Portuguese]: "Yeah, who is this?"

(4) $f / v$ Rachel E [In Portuguese]: "It's Antonio Pimental. Hey, that guy is bad where he is."

(5) Don't you think that guy is wrong in that area."

(6) $\mathrm{f} / \mathrm{v}$ Sao Marcos [In Portuguese]: "I just tried to call him. He didn't answer back. He is wrong."

(7) $f / v$ Rachel E [In Portuguese]: "I've been watching him for the last half hour. He was a big

(8) contact on my radar. I picked him up 8 miles away."

(9) [unknown source] [in English language]: "Channel 16 is a distress channel and this is international,

(10) please change your channel, please change your channel."

(11) 2045 f/v Rachel E [in English language]: "Calling the cruise boat in position 41 02N, $6924 \mathrm{~W}$. Over."

Source: NTSB (1995)

According to the SMCP, communication at sea consists of the following stages (Pritchard, 2003):

1. Making contact,

2. Exchange of information,

3. End of procedure.

In the initial phase or making contact, the address or station which is called is to be called two or three times after which the station which is calling is to be identified. After this, VHF channel is to be agreed followed by a turn-giving signal "over" (Pritchard, 2003).

Apart from the rules prescribed in the SMCP, real conversations between station differ, depending on the participants in communication and working context. Thus, the above illustrated segment of communication lacks the formal structure of the pattern making contact, information and ending, as the communication is conducted in an unformal setting among ships whose crew know each other.

In an attempt to address the cruise boat Royal Majesty, the fishing boat Sao Marcos did not use the standard SMCP format of initial call, known as "making contact" by which the name of the ship/station, if the name of the ship/station is known, is to be pronounced two or more times. Therefore, the initial call made by Royal Majesty: "Fishing vessel, fishing vessel call cruise boat" is not complying with the SMCP and moreover, the etiquette "cruise boat" is too indefinite way to address any vessel in the navigable part of the fairway.

Communication was then conducted in Portuguese, in a rather informal tone. Code switching (the shift from Portuguese to English language by the fishing vessel Sao Marcos) adds an informal tone to the communication and make it "reserved" for the Portuguese-flagged ship. The ignorance of English language can be interpreted either as language incompetence of the Portuguese crew or as a deliberate deviation from the mandatory language at sea.

In any case, communication is unintelligible to the ships which do not speak Portuguese and in that way closed. The informal tone of communication is also evident in addressing the ship, as the ship Rachel $E$ does not address Sao Marcos by name (2), but by its nickname (Toluis). In addition, communication among Portuguese ships is conducted in 
a chat mode. This is realized through the metaphorical use of language, so the ship Royal Majesty is called "bad guy" (Table 3, line 4) which "is wrong" (line 6) instead of indicating clearly that the ship Royal Majesty is on the wrong route.

Apart from failure to comply with the standards of communication, the fishing boats used channel 16 which is designed for the use of routine communications and distress messages. Any communications used on the channel 16 must be clear and in English, the standard language of communication in the international waters (9). In addition, calling of the ship is contrary to regulations, as the fishing boat Rachel $E$ called the ship Royal Majesty addressing it not by name, but as a "cruise boat". This would be acceptable address format in an informal communication between two ships whose masters know each other and whose ships are in immediate vicinity. However, this address format is not allowed on channel 16 in a situation in which one of the ships is on a dangerous course. If the name of the ship/ station which is being called is unknown, the initial call should be made to using the prefix "all stations" or "all ships" (Pritchard, 2003).

The issues relating to multicultural crews and maritime accidents related to communication and language at sea, were explored by the authors Pyne and Koester (2005). Examples of marine accidents at sea were analyzed using the ADREP 2000 taxonomy (taxonomy based on psychological rather than technical facts in analyzing marine accidents). According to this approach, the two authors identified the problem of Royal Majesty communication failure as "the interface between humans in relation to language".
Pyne and Koester (2005) apply in their analysis of marine accidents the Metze and Nystrup model. With most professional discourses, there is an identifiable communication sequence (conversation, question, answer, order, etc.), which can be analyzed according to one of the following dimensions:

- Cognitive (exchange of factual information) and affective (feelings);

- Expanding (longer conversations, dialogues or questions leading to broad answers) and limiting (short yes/no answers or short sentences aimed at ending conversation);

- Confronting (problems and conflicts are evident) or concealing (problems and conflicts tend to be hidden);

- Listening (focus is on listening to what is said which is followed by adequate gestures and replies) or not-listening (no eye contact, unresponsive, not paying attention to what is said).

Applying the Metze and Nystrup model, communication among vessels in the Royal Majesty case can be categorized as partially cognitive (about facts, i.e. $M / V$ Royal Master is on dangerous course), confronting (there is an imminent danger on the fairway), and to the greatest extent, concealing (communication was conducted in mother tongue of the fishing vessels, i.e., in Portuguese).

The author of this paper agrees with this approach adding to the discourse analysis an intercultural approach based on the theory of cultural script based in Wierzbicka's theory and linguistic "power" of English language, being a mandatory language of marine communication. 
However, Wierzbicka's (Wierzbicka, 2006) theory referred to in this paper as far as the intercultural approach is considered seems to be relevant in the analysis of the above mentioned segment of discourse, particularly with reference to the concept of code-switching. Therefore, intentional use of mother tongue rather than English language in the Royal Majesty communication case among ships flying the same flag (Portuguese), raises the question of cultural script, with regard to a deliberate shift to English from Portuguese in the case of fishing vessel Rachel E (Portuguese fishing vessel Rachel $E$ firstly communicates in English with Portuguese ships but shifts to English when she was warned by an authorised channel). According to Weirzbicka (Weirzbicka, 2006), those nations whose cultural scripts oppose the Anglo-Saxon one, either reluctantly use English because of its cultural script, or simply certain nations resent the power of English cultural concept manifested through the language, i.e., encrypted in English language.

\section{Another Example of the Internal Communication - Allision of the Ship MV Cosco Busan with Delta Tower}

The aim of analysis of the following internal segment of the verbal communication is to point out to the fact that apart form the external communication (ship-toship and ship-to-shore communication), the crucial importance for the ship's safety is the internal communication, i.e. communication among the ship's members on board. The allision of the ship MV Cosco Busan, with the fendering system of the Delta Tower in San Francisco-Oakland Bay Bridge in 2007 is taken as an example in which different navigational factors, along with bad communication resulted in the maritime accident. According to the data stated in the final report, apart from the pilot's incapability to predict danger, the master's over-reliance on the pilot's assessment and his lack of personal effort in manoeuvring the ship, there is an evident lack of good communication between pilot and master before the ship's departure. Part of the blame is laid with the vessel traffic information service which did not adequately communicate the warning about the collision to the ship Cosco Busan.

According to the transcript retrieved from the Voyage Data Recorder (VDR), the ship called the vessel traffic information service in the morning about 0600 and informed them of its intention to leave the berth and pass through the Delta-Echo bridge span, after which manoeuvre it would enter the traffic lane. The conversation between the pilot and master about the routine manoeuvre of the ship's departure is rather informal. In the navigational situation "pilot on board", the rule is that the pilot performs pilotage in coastal waters, but it should be emphasized that the final responsibility for decisions lies with the master, which is known as the "under Master's orders and pilot's advice" rule. What follows is a piece of communication between master and pilot (Table 4): 


\section{Table 4}

MV Cosco Busan Bridge Allision, Segment of the Internal Communication between Master and Pilot before the Ship's Departure from the Channel

(1) Pilot: So, Captain, there's a ... tug and a barge coming in. We let them come in first and

(2) then-cause you can see the other side now, and there's no more traffic-this looks good.

(3) The current's not very strong. It's coming this way, so I think we'll be able to go as soon

(4) as the tug and the barge go past us.

(5) Master: "Yeah, yeah, yeah."

(fifteen minutes later)

(6) Pilot: You can single up Captain if you want.

(7) Master: OK, single up.

Source: NTSB (2009)

As demonstrated in the above table, discourse is in conversational style. The master thoroughly relied upon the pilot and did not at any moment question either the procedure of unberthing or the pilot's information about visibility and manoeuvring (the order "single up") before departure.

As regards the informal communication between the pilot and the master in the above illustrated segment and further throughout the text, it must be emphasized the SMCP require high level of hierarchy of pilot-master discourse in a ship's departure scenario. Thus, the dialogue between master and pilot should have the form of military and highly predictable discourse (coming from the aviation language). Although the SMCP are often criticized due to redundant phrases and repetition, they are seen as possible solution in overcoming evasiveness of expression, like in "Yeah, yeah, yeah" or "OK, single up". Instead of short sentences like with "OK", "Yes", "No", "Roger", full sentences are recommended (Pritchard, 2003). Thus, the master should have repeated Pilot's orders or ask for a clarification.

About 0800, the ship shifted from the berth with the help of a tug and the only audible recording, according to the Voyage Data Recorder transcript documents, is a comment by the Mandarin crew member who said "... American ships under such conditions, they would not be under way" (National Transportation Safety Board, 2009). Therefore, despite bad visibility, the ship started with a departure manoeuvre. The crew member did not share his observation with any of the senior crew members, nor did he use English.

At the time of departure from the channel, the master, the pilot, the third officer and a helmsman were on the bridge. Towing continued and the ship was sailing with difficulty owing to its deep draft. According to the VDR, about 0822 the pilot addressed the master referring to meaning of the electronic chart:

(8) Pilot: "What are these... ah ... red [unintelligible]?"

(9) Master: "This is on bridge."

(10) Pilot: "I couldn't figure out what the red light... red... red triangle was."

Information about the "red triangle" is a crucial navigational factor, however, the master understood the pilot's question as pure curiosity. When the ship Cosco Busan was near the bridge, the VTS operator who was monitoring the traffic in the central 
sector and steering of the ship Cosco Busan, noticed its vicinity to the Delta-Echo bridge span. The VTS radio operator then addressed the pilot of the Cosco Busan.

Instead of calling the ship by its name, the VTS station addressed the ship with "Romeo". In the same way, the pilot addressed the VTS San Francisco station with "traffic". In this way, communication is not open to other ship stations as pilot-VTS communications take the form of a private conversation.
Moreover, the communication was thus closed to the ship's master himself. Apart from this deviation from the standard radio discourse, it may be said that the VTS station in general complies with the Standard Marine Communication Phrases used in conducting the VHF communication (Table 5): "What are your intentions? Over" (5), "Roger" (10). It also noticeable that pilot of the ship Cosco Busan answers in a rather informal, conversational tone: "Well, I am coming around" (6), "Yeah, we're still Delta-Echo" (9).

\section{Table 5}

MV Cosco Busan Bridge Allision, Segment of the External VHF Communication between Pilot and the VTS Station before Ship's Departure from the Channel
(1) VTS 08:27:24 Unit Romeo, Traffic.
(2) Unit Romeo 08:27:29 Traffic, Romeo.
(3) Unit Romeo 08:27:45 Traffic, Romeo, did you call?
(4) VTS 08:27:48 Unit Romeo, Traffic. AIS shows you on a 235 heading.
(5) What are your intentions? Over.
(6) Unit Romeo 08:27:57 Well, I'm coming around; I'm steering 280 right now.
(7) VTS 08:28:04 Roger, understand you still intend the Delta-Echo span.
(8) Over.
(9) Unit Romeo 08:28:15 Yeah, we're still Delta-Echo.
(10) VTS 08:28:21 Uh, roger, Captain.

Source: NTSB (2009)

Shortly after this pilot-VTS conversation, the onboard conversation between pilot and master continued. The pilot wanted to clarify the meaning of the symbol on the electronic chart, more precisely, he wanted to know what it referred to. He addressed the master: "This is the centre of the bridge, right?" What followed is a rather reluctant master's response: "Yeah.".

Over the next minutes, after additional manoeuvres were made in order to avoid allision the Bosun yelled on his radio in Mandarin: "The bridge column. The bridge column!" after which the pilot, also in Mandarin, replied: "Oh, I see it. I see it". The vessel struck the fender of the Delta-Echo span. After the master and pilot had become aware of the situation, the discourse became strained, some words are unintelligible, master stammers (Table 6, line 8) and sentences are unfinished and unclear (Table 6, lines 1, 5 and 6). They attempt to manage discourse cohesion by the use of demonstratives in the function of anaphoric and cataphoric reference. The anaphoric reference is realized at the beginning of a discourse by a demonstrative this which replaces red triangle. As regards the examples of the cataphoric reference found in the Table 6, those are: "This is the centre" (3) , "this is the tower" $(3,6)$, "it's a buoy" (5), whereas the anaphoric reference 
is realized in the examples: "that's why we hit it" (3), "I thought that was the centre" (3), “I asked you if that was" (6), "Captain you said it was the centre", "Yeah, that's the bridge pier, I thought it was the centre" (9).

According to the IMO SMCP (2001) any important information is to be prefixed by the word "repeat" followed by the corresponding message.

Thus, instead of the random use of this and that as in the illustrated example, the speakers should use lexical or full words carrying crucial meaning at the given situation (read triangle, tower, centre, bridge column).

\section{Table 6}

MV Cosco Busan Bridge Allision, Segment of the Internal VHF Communication between Master and Pilot after Ship's Allison with the Delta-Echo Span

(1) Pilot: [unintelligible] you said this was the centre of the bridge.

(2) Master: Yes.

(3) Pilot: No, this is the centre. That's the tower. This is the tower. That's why we hit it. I thought that was the centre.

(5) Master: It's a buoy. [unintelligible]

(6) Pilot: Yeah, see. No, this is the tower. I asked you if that was [unintelligible]....

(7) Captain, you said it was the centre.

(8) Master: Cen... cen ... cen ... centre.

(9) Pilot: "Yeah, that's the bridge pier, I thought it was the centre".

Source: NTSB (2009)

According to the report from the postaccident interviews with the master and pilot, it may be said that there was an evident lack of communication. As regards the pilot's radio conversation with the VTS, the master complained of the pilot's negligent and private conversation with the VTS and said that he did not take the pilot's questions about the red triangle "as a serious question". "If the VTS called the pilot's or the person's name, it may be private conversation. If for working, I think it's best way to call ship's name because when you call ship's name, not only pilot would understand that, even the captain understands" (National Transportation Safety Board, 2009). As far as other ship's officers are concerned, they complained of the complete lack of training and communication by the Fleet Management before the ship's departure.

Using the method developed by Pyne and Koester (2005) in their work, the bridge communication between master and pilot and communication between the ship and the VTS may be classified as cognitive (conversation about navigational facts), whereas bridge communication (masterpilot) may be classified as limiting (instruction-acknowledgment military discourse sometimes lacks master's feedback), and therefore concealing (imminent allision situation was concealed due to master-pilot misunderstanding and the Mandarin crew member's observation communicated in Mandarin language.

Mother tongue interference and the shift from English to Mandarin language is another example related to bad communication which directly contributed to the accident. However, as it has already been mentioned in the above text, it is difficult to determine if and when language errors overlap with the cultural issues. Thus, 
it may be assumed that in the case of the $M / V$ Cosco Busan bridge allision either the pilot and Mandarin crew member converted to Mandarin after they had become aware of the incident (psychological nature), or their use of Mandarin rather than English was a deliberate way to mitigate danger and real situation at sea. Linguistically, the use of Mandarin is interpreted as a lack of language skill of linguistic competence, whereas from the aspect of sociolinguistics, it may be seen as a verbal escape from responsibility, which implies the use of English language, the official language of the marine communication. The use of English thus involves discipline and compliance with the rules (the SMCP as a language of marine VHF communication at sea) and any "departure" (using a nautical term) is to be interpreted as a breach law.

\section{Conclusion/Recommendations}

The analysis reported in this paper has taken segments of verbal communication at sea to point out how the prescribed language set by the Standard Marine Communication Phrases "works" in certain situations at sea. A discursive analysis focuses on language per se and compliance or deviation from the prescribed standard (the IMO SMCP). There is no doubt that in emergency situations at sea, a discourse takes over syntactic, discourse and lexical features of everyday language, and therefore the transition on the formal/informal discourse continuum here becomes most prominent. In addition, not less important attitude taken in this paper, apart from discursive facts, is to point out to the cultural aspects brought by English language as the lingua franca of marine communication. Setting aside the linguistic factors related to the use of language pertaining to its grammar, communication lapses are inevitably the result of cultural clashes. The question is whether the cultural script with which English language is endowed clashes with other different cultural scripts presented by non-English crew.

Deviation from the use of the formal or prescribed forms in communication at sea is mostly present in situations of immediate danger or heavy traffic. There is no doubt that the very situation at sea dictates a discourse. It seems that the communication gap is present in communications between ships flying the same flag when the communication often takes the form of slang. In addition, the example with the Portuguese fishing ships communicating in Portuguese as well as the example with the officer from the Cosco Busan addressing his colleagues in Mandarin, raises the question of language interference and code switching in situations of immediate danger.

Analysis showed that certain segments of communication are characterized by military and hierarchical discourse and lexis which mainly depends on the participants in the communication. Thus, compliance with the Standard Marine Communication Phrases and the standard radio forms is used to the greatest extent by the vessel traffic information service operators. Messages are mainly short, clear and communicated "by the book" (the use of the prescribed message markers such as "information", "warning" and specific standard marine communication phrases such as "keep a good lookout"). On the other hand, language is less predictable in a discourse carried out between ships when no external authority is present (the VTS).

To sum up, the more regular the situation on board and at sea, the more regular discourse 
is expected. Bearing in mind the specific maritime vocation, it seems that no matter how one tries to tame verbal communication at sea, the truth is that it is spoken differently by different people. No matter how far the maritime technology goes, accidents happen because it takes time to internalize "limited languages" such as the Standard Marine Communication Phrases and to make seafarers use it in real situations at sea.

Finally, the idea supported here is that no matter how linguistically correct the SMCP may be, nations or people whose collective discourse pattern is not complying or even opposing the "Anglo-Saxon cultural script" will have difficulties in communicating in English and achieving their social position onboard. Therefore, apart from the problem of compliance and non-compliance with the SMCP in the illustrated situations, the fact is that linguistic hegemony carried by English and English nation implicitly affects human relationships and verbal behaviour in ship to ship and onboard communication. Given that internationalism, social harmony and safety stand for key concepts in seafaring, the theory of cultural script is of relevance in explaining certain discursive features of the participants in multi-cultural interactions. Thus, Maritime English teachers and professionals must have knowledge of intercultural issues and raise students' awareness of possible cultural clashes in the multicultural context. In short, some individuals or nations are by its nature language-sensitive and this must be borne in mind in the multicultural surroundings, such as that found onboard ship.

Anyhow, communication error is one of the errors made by human (human factor, human element, human error) and represents "unacceptable and unwanted behaviour of an individual or group the consequence of which is incident, accident or danger on board ship" (MARCOM project, 1999).

\section{References}

Austin, J. 1994. Kako delovati rečima (in Serbian). Novi Sad: Matica srpska.

Bocanegra-Valle, A. 2010. Global markets, global challenges: The position of Maritime English in today's shipping

Industry. In: Professional English in the European context. The EHEA Challenge, Peter Lang, 151-180.

Gotti, M. 2008. Investigating Specialized Discourse. Bern: Peter Lang.

Hatch, E. 1992. Discourse and Language Education. Cambridge: Cambridge University Press.

Heritage, J. 2001. Goffman, Garfinkel and Conversation Analysis. In M. Wetherell, S. Taylor \& J.S. Yates (eds.), Discourse Theory and Practice: A Reader. London: SAGE Publications, 47-57.

IMO Standard Maritime Communication Phrases. Resolution A.918 (22), 29 November 2001. London: International Maritime Organization.

Lazaraton, A. 2009. Discourse Analysis. In: J. Heigham and R.A. Croker (eds.). A Qualitative Research in Applied Linguistics, London: Palgrave Macmillan, 201-226.

MARCOM project. 1999. The Impact of Multicultural and Multilingual Crews on Maritime Communication Final Report-Volume 1. Brussels: Transport RTD Programme.

MAIB (Marine Accident Investigation Branch). 2009. Investigation Report Maersk Kendal. Available from Internet: <http://www.maib.gov.uk/publications/ investigation_reports/2010/maersk_kendal.cfm $>$. 
NTSB (National Transportation Safety Board). 2009. $M / V$ Cosco Busan Bridge Allision, San Francisco, California. Available from Internet: <http://www.ntsb. gov/doclib/reports/2009/MAR0901.pdf $>$.

NTSB (National Transportation Safety Board). 1995. Grounding of the passenger ship Royal Majesty. Available from Internet: <http://ti.arc.nasa.gov/m/profile/ adegani/Grounding $\% 20$ of $\% 20$ the $\% 20$ Royal $\% 20$ Majesty.pdf $>$.

Pritchard, B. 2003. Maritime Communications and IMO SMCP 2001 (draft version). Available from Internet: <http://www.pfri.uniri.hr/ bopri/documents/ MaritimeCommunicationsandSMCP_001.pdf $>$.

Pyne, R.; Koester, T. 2005. Methods and means of analysis of crew communication in the maritime domain, The Archives of Transport, 17(3-4): 1-16. Available from Internet: <http://general.marine-files. net/upload/Methods and Means for Analysis of Crew Communication in maritime domain.pdf $>$.

Savić, S. 1998. Diskurs Analiza (in Serbian). Novi Sad: Filozofski fakultet.

Schegloff, E.A. 1992. To Searle on conversation. In: H. Parret and J. Verschueren (eds.) Searle on Conversation, Amsterdam: John Benjamins, 113-28.

The Standard Marine Navigational Vocabulary (SMNV). 1987. London: International Maritime Organization.

Wierzbicka, A. 2006. English: Meaning and Culture, Oxford: Oxford University Press.

Wooffitt, R. 2005. Conversation Analysis and Discourse Analysis: A Comparative and Critical Introduction. London: Sage Publications Ltd. 29-32. 